\title{
Disruptions on India's FinTech landscape: The 5G wave
}

\author{
Mohanasundaram $\mathrm{T}^{1, *}$, Sathyanarayana $\mathrm{S}^{2}$, and Rizwana $\mathrm{M}^{3}$ \\ 1,3 Department of Management Studies, Ramaiah Institute of Technology, Bengaluru, Karnataka, India \\ ${ }^{2}$ M. P. Birla Institute of Management, Bengaluru, Karnataka, India
}

\begin{abstract}
The emergence of FinTech companies disrupts the banking and financial service industry through its technology-driven services. But with $5 \mathrm{G}$, the 5 th generation mobile network, the entire FinTech outlook is disrupted. The $5 \mathrm{G}$ technology is expected to create a new FinTech ecosystem in India. The $5 \mathrm{G}$ features like enhanced mobile broadband (eMBB), Lower latency and robust security aspects are certain to bring transformation in banking and FinTech industries. 5G's application in different domains offers a 'blue ocean' of new prospects to FinTech companies.5G technology offers necessary features to enable FinTech companies to bring a massive change in the banking and finance field. As $5 \mathrm{G}$ is on the brink of being a next-generation mobile network in India, it is necessary to examine its influence on the FinTech landscape. In this study, the authors have analyzed the effect of $5 \mathrm{G}$ on evolving bank technologies, with special focus on FinTech. This study also projects the authors' view on the impact of $5 \mathrm{G}$ on FinTech firms' future challenges and prospects.

Keywords: 5G, FinTech, disruption, Banking, Financial services, digitalization.
\end{abstract}

\section{Introduction}

5G technology enables the new industrial revolution, industry 4.0. A huge ongoing automation is in progress across different sectors. Innovative and life-enhancing business models are emerging and creates disruption in the way business functions. The arrival of $5^{\text {th }}$ generation (5G) telecommunication technology is expected to create new ecosystems of Fintech and digital banking by offering new features and tools. $5 \mathrm{G}$ technology is creating new business models in the financial industry and expected to change financial landscape, especia lly in FinTech. There is a growing attention from the international tech firms to make a way into financial industry. $5 \mathrm{G}$ features and its potential applications include: (i). Enhanced Mobile Broa dband (eMBB) for virtual reality and improve video conferencing with extreme network speed and processing ca pability. (ii). Highly reliable and low latency in processing a very large volume of data. (iii) Massive Machine to Machine Communication enabling Internet of Things (IoT) etc., and (iv). Robust security a spects lea ding to high reliability. Innovation is the need of any business which is all about novel thoughts that produce great value. We are living in the age of digitalization and we are constantly moving in that direction by adopting pioneering technology to ensure more effective and prolific way of life. In the area of Finance too, we are consistently upgrading the products, services, methodology and system with new technology.

The financial sector is one of the largest users of digital technologies. Such innovation and upgradation in Finance through technology is known as FinTech (Financial Technology). Fin Tech as a concept developed only in the $21^{\text {s }}$ century. FinTech is the combination of 'Financial Service' and 'Technology'. The adoption of technology in the field of financial services viz., Banking, Share market, Insurance sector, Mortgage loans etc. with database management, a nalytical tools, and innovative approach. The prominent operators of FinTech are; Banking and Insurance sector, Financial Institutions, Small and Medium Enterprises (SMEs), Start-ups, and individuals. Since 2016, India is a ctively engaged with Fin Tech after the demonetization of high denominated currency notes. From then, Unified Payments Interface (UPI) payment technique is highly engrossed by the Government of India. Many startups started using innovative technology to make easy and cashless payments. FinTech will phy an important role in achieving the cashless economy. [1] stated that the scope of FinTech is huge, as there were 1,400 FinTech firms existed in 2015 with investment of more than $\$ 33$ billion.

Digitalization not only minimizes the time and cost but also increases efficiency. The fintech industry has progressed enormously from cha llenging and team up with traditional banks and has today entered a new era at the front of digital revolution prioritizing technology. The digital revolution has shaped several innovative technologies but none of them had a massive widespread influence than internet and mobile communication technology. These technical revolutions independently have transformed the way we communicate with others, but collectively, they have transformed the entire world. $5 \mathrm{G}$ 's a pplication

\footnotetext{
*Corresponding author: tmohansun@gmail.com
} 
in different domains offers a 'blue ocean' of new prospects. [2] referred blue ocean as a rise of an entirely new industry or developments in the prevailing industries that amends the boundaries of competition. The most apparent opportunities from a bank and financial service institution's viewpoint is the sustained progress of digital ba nking solutions aimed at each distinct customer. These digital devices and Fintech firms endlessly collect data on each customer [3]. 5G being the next-generation technology is expected to change the role of mobile in society. $5 \mathrm{G}$ a lone is forecasted to a dd $\$ 2.2$ trillion to the world economy ${ }^{2}$. Improved connectivity, facilita ted by $5 \mathrm{G}$ technology, shall be a catalyst for economic growth in the Industry 4.0 with a projected economic value of $\$ 13.2$ trillion by $2035^{3}$.

The mobile-oriented business restructuring is undergoing in banks and financial service fims by functioning meticulously with Fintech providers for providing better services, retaining their current customers, and attracting new or potential ones. As $5 \mathrm{G}$ is on the brink of being a next-generation mobile network in India, it is necessary to analyse its effect on the FinTech landscape. In this study, the authors have analysed the effect of $5 \mathrm{G}$ on evolving bank technologies, with special focus on FinTech. This study also projects the authors' views on future challenges and opportunities.

\section{Fintech Industry - An Overview}

As the name 'FinTech' proposes, it is the blend of fina ncial service and technology. FinTech comprises many tools and technological a dvancements that are way different from traditional banking. In recent years, a vast number of FinTech firms a re coming into the marketby offering a variety of new financial solutions and services that are in great demand.

Fig.1. Fin Tech

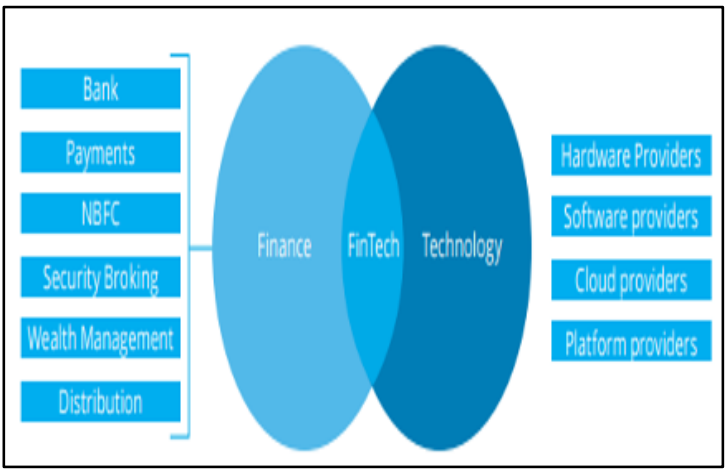

Source: Deloitte International Analysis

FinTech is an application of technology to offer novel and better financial services. Technology has been a crucial facilitator in the digital economy's expansion. Over the time period, banks and financial institutions in India have gradually and carefully

\footnotetext{
${ }^{2}$ GSMA report 2018 'Study on Socio-Economic Benefits of $5 \mathrm{G}$ Services Provided in mmWave Bands'
}

a dopted technology to expand the reach, service and working efficiency with growing market and a dvancements in technology.

In today's world, financial institutions have higher significance; and even a minor change makes an enormous impact on the global economy. Although finance as a domain met numerous demanding revolutionary waves over the period, it has succeeded to adopt and endure from those changes. At present, financial institutions and the industry as a whole are witnessing massive change because of FinTech. The consequences of this change are yet to be fully explored and they may bring a huge challenge for different stakeholders viz., policymakers, academicians, service providers, intermediaries, economists and the general public. [4] specified that information technology will inspire the specialized firms which are generating niche markets with superior customized product in order to ca ter to consumer preferences. Peer-to-Peer (P2P) lending, cryptocurrencies and many other innovations of all segments of an emerging technology-supported personalized financial services. FinTech has come a long way since its evolution and is expected to reach much greater heights in the days to come.

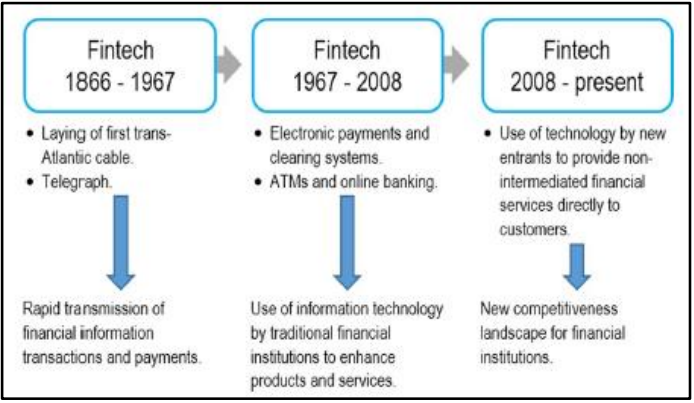

Fig. 2. Pha ses in Fintech Evolution

Source: Consumers International, 2017

Technology has constantly a ffected the finance industry with developments thereby altering the way the finance industry functions. For example, the emergence of Automatic Teller Machines (ATM) or Online transactions of money were some of thekey innovations in Financial service. It is interesting to know that what makes the current FinTech revolution so special than earlier innovations? First and foremost, the speed at which new innovative financial know-how and technologies are tested is much quicker than earlier. Secondly, the most crucial thing about FinTech revolution is; it is unique, as the change happening is from the extemal environment (i.e.) new start-up firms and large recognized technology companies a re endeavouring to intrude the financial services by presenting

\footnotetext{
${ }^{3}$ The impact of 5G: Creating new value across industries and society, World Economic Forum report.
} 
innovative products and technologies thereby offering a significant competition in an innovative manner.

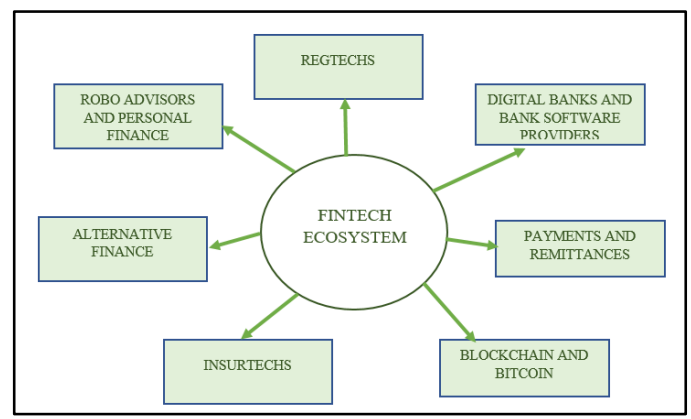

Fig.3. Fintech Ecosystem

FinTech firms' ecosystem includes various stakeholders, partnering institutions, technology platforms and regula tory compliances. [5] in their book discussed the FinTech revolution to high light the persistent disruption and to create methods for analyzing flash crashes, hostile high-frequency trading, and other specific facets of the market. According to the IMF, a mong the low- and middleincome countries, India has grown phenomenally in the number of registered mobile money a ccounts between 2015 and 2019. India had witnessed 17-fold jump during that period ${ }^{4}$. [6] observed that big strides happened in different fields such as mathematics, big data, computing technology, statistics, econometrics and cryptography have integra ted well to make an explosion of Fin Tech.

\section{5G Technology in FinTech}

Change in any form is not easy to deal with, particularly when it happens in banking and financial services, as the process involved and the number of stakeholders is very high. In a digital era, the speed and ability of data transfer a long with compatibility of data are vital for FinTech to prosper. The $5 \mathrm{G}$ technology just offers those features to enable FinTech companies to bring a massive change in the banking industry. Rapid internet speed has become imperative for improved financial transactions. $5 \mathrm{G}$ also has an edge at handling heavy load compared to the previous technologies. 5G will certainly help the FinTech players to bridge the gap between the existing reality and customer expectation by offering safer and faster service to end-users. 5G mobile technology services a lso support FinTech companies to provide affordable loans by refining the lenders' assessment of borrowers based on financial soundness. $5 \mathrm{G}$ is expected to disturb information security, machine learning, IoT, da ta management system etc. which

\footnotetext{
${ }^{4}$ Mobile money a/cs: IMF says 17 -fpld jump in 4 years in India, Financial express dated 11.11.2020 - retrieved on 06.12.2020.
}

are used extensively by FinTech companies. In the Banking and Financial Services industry (BFSI), 5G will be mainly useful in making communications more secured, processing real-time information and improving customer experience. $5 \mathrm{G}$ services have the potential to connect numerous devices, minimize power consumption, reduce latency, offer higher security, and better support for a ugmented/virtual rea lity experience. It enables to manage millions of IOT devices. 5G mobile technology will empower the extensive implementation of blockchain, artificial intelligence, machine learning and quantum computing. The Organization for Economic Cooperation and Development (OCED) predicts an upsurge in world GDP, higher employment and digitalization with quick $5 \mathrm{G}$ penetration.

Being new and technology-driven company doesn't assure a new player an easy joumey especially when it comes to lega 1 compliance. $5 \mathrm{G}$ along with RegTech will help the financial institutions to better adhere to the legal compliances, and this is more important for the banks and institutions operating at the global level asthey have to comply with numerous lega la spects and noms. India is having a good $4 \mathrm{G}$ connectivity which leads to the highestmobile data consumption in the world, offers a great potential for 5G technology implementation. According to Ericsson, India has the world's highest da ta usage per smartphone at an a verage of $9.8 \mathrm{~GB}$ per month and this is expected to double to $18 \mathrm{~GB}$ by 2024 . As the financial institutions seemingly leverage the value of data, the method in which the data is gathered, warehoused and deployed are sprouting to ma intain pace with ever-growing customer expectation and legal requirem ents. The benefits of $5 \mathrm{G}$ in banking include; enriched ATM facility with features like virtual rea lity in order to directly interact with the bank, enables richer customer experience with lower cost, Risk prevention, complying with regula tory norms. $5 \mathrm{G}$ technology a long with blockchain and other revolutions will affect different areas in finance like capital markets, cross-border payments, automated payments, mobile banking etc. $5 \mathrm{G}$ provides an extensive platform for Fintech firms to innovate. Australian telecommunication providers have rea lized speeds up to $1200 \mathrm{Mbps}(1.2 \mathrm{Gbps})$ in $5 \mathrm{G}$ testing ${ }^{5}$ which is significantly higher than $20 \mathrm{Mbps}$ to $50 \mathrm{mbps}$ in $4 \mathrm{G}$ technology. No doubt, if implemented, 5G will immensely improve the user experienceand real-time delivery of services.

Startups in Finance are providing computeried a utomatic guidance, touchless payments, and many other services that brings many social a nd economic benefits which includes lesser prices and better

\footnotetext{
${ }^{5}$ The Future of Digital banking, KPMG, 2019.
} 
access to credit. Purely from the perspective of product categorization, fintech's role can be split into those providing credit, payments process, delivering advice, asset management and legal compliance. Fintech being a rela tively new category of companies, the business models are based on digital products. In spite of intensive competition from large technology firms, the chief driving force of fintech innovation has come from numerous technology-based startups attracting investments in billions of dollars each year. India is doing fainty well in adopting FinTech compared to most other nations.

The destructive impact of the global financial crisis in 2008 has created every reason to suspect the purpose and working ethics of financial services firms across the globe. Even big financial institutions all a cross the world suffered the worst from both economic as well as from public trust perspectives. The failure of big firms to meet the expectations of different stakeholders has opened the doors for a small-scale innovative technologybased financial institution. The substitute to existing banks a nd financial institutions emerged with small, controllable, and transparent features. Therefore, it is judicious to express that the global economic and financial crisis in 2008 signified the landmark to trigger fintech 3.0 phase. As Fintech firms move towa rds $5 \mathrm{G}$ service, the likelihoods of forming truly universal financial services turn out to be a greater rea lity. International firms view $5 \mathrm{G}$ as a disruptive technology of this era. The lea ding global a eroplane manufacturing firm, Boeing has a lready created a tech-based ecosystem for its commercial planes [7]. Many international banks like JPMorgan Chase, Bank of America, Citigroup and leading Fin Tech companies like, Ant Fina ncial, Paypal, Qudian, etc. are actively penetrating $5 \mathrm{G}$ technology in their ecosystem to reap the benefit out of it.

Table. 1. Fin Tech Country Ranking

\begin{tabular}{|c|c|c|c|c|}
\hline $\begin{array}{c}\text { Globol Fintech } \\
\text { Rank }\end{array}$ & $\begin{array}{l}\text { Chang } \\
\text { Storte }\end{array}$ & $\begin{array}{l}\text { from } \\
\text { Ronk }\end{array}$ & Country & Total Score \\
\hline 1 & $>$ & $=0$ & United States & 31.789 \\
\hline 2 & $>$ & $=0$ & United Kingdom & 23.262 \\
\hline 3 & $\Delta$ & +18 & Singapore & 19.176 \\
\hline 4 & $\Delta$ & +14 & Lithuania & 17.343 \\
\hline 5 & $\Delta$ & +3 & Switzerland & 16.018 \\
\hline 6 & $>$ & $\approx 0$ & The Netherlands & 14.464 \\
\hline 7 & $>$ & \pm 0 & Sweden & 14.272 \\
\hline 8 & $\boldsymbol{\nabla}$ & -3 & Australia & 13.555 \\
\hline 9 & $\boldsymbol{\nabla}$ & -6 & Canada & 13.322 \\
\hline 10 & $\Delta$ & +3 & Estonia & 13.303 \\
\hline 11 & $\boldsymbol{\nabla}$ & -2 & Germany & 12.787 \\
\hline 12 & $\boldsymbol{\nabla}$ & -8 & Israel & 12.771 \\
\hline 13 & $\boldsymbol{\nabla}$ & -3 & Spain & 12372 \\
\hline 14 & $\boldsymbol{\nabla}$ & -2 & Finland & 12.110 \\
\hline 15 & $\Delta$ & +2 & India & 12.024 \\
\hline
\end{tabular}

Source: $w w w$ findexable.com

FinTech firms such as GoCardless, Transferwire, Currency cloud etc are started disrupting the Forex market by competing aggressively with the bigger banks having larger market shares. [8] suggested that the digital footprints may be used to assess individual default risk. FinTech companies across the globe are attracting huge investments from a different set of investors like investment banks, venture capital firms etc. Fig. 5 will depict the quantum of investments happening in FinTech companies worldwide.

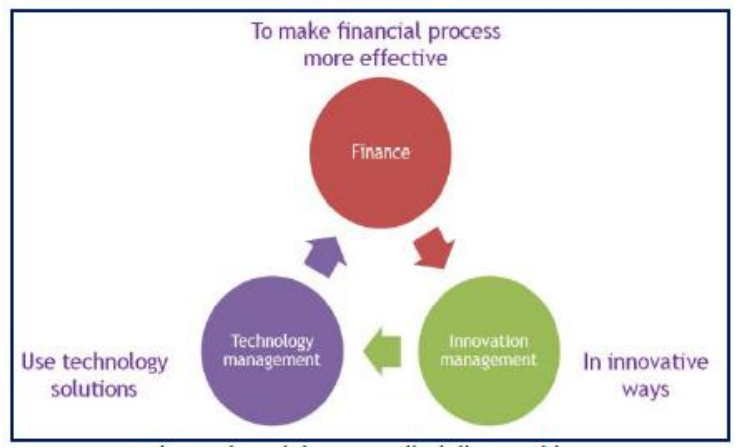

Fig. 4. Fin Tech - Cross Disciplinary nature

\section{India and 5G Services in FinTech}

$5 \mathrm{G}$ primarily functions in three bands- low, midand high-frequency spectrum - each having their own advantages and limitations mainly on account of speed and coverage. In 2018, India had intended to start 5G technology at the earliest possible. The major telephone players in India have urged the Department of Telecommunication (DoT) to roll out a detailed future plan on $5 \mathrm{G}$ frequency bands and spectrum allocation. However, Reliance Jio planned to unveil its own $5 \mathrm{G}$ network. The major challenges of $5 \mathrm{G}$ in India are; inadequacy of spectrum and TRAI's higher reserve price for spectrum auction. $5 \mathrm{G}$ has the ability to a ugment the day-to-day use of banking products and services. The financial institutions that embrace $5 \mathrm{G}$ technology are effectively poised far a head of its riv als as they enjoy offering data-backed personal services for the customers of Gen Z. Moreover, $5 \mathrm{G}$ can overcome the major shortcoming of earlier technologies inefficient handling of increased financial transactions.

5G potential in Indian banking and FinTech domain is boundless as the arrival of $5 \mathrm{G}$ coincides with a boom in Internet of Things (IoT) inventions, including smartphones and wearables. This will help banks and fintech firms to make seamless financial transactions, innovate and to provide secure services to their customers. $5 \mathrm{G}$ could also enable highfrequency trading and effective diversification of the bank's portfolio. $5 \mathrm{G}$ services may be effective in capturing how sentiment analy sis can be used to gain more customer understandings. No doubt, $5 \mathrm{G}$ will bring innovative and better services apart from bringing more digital-savvy users for the banking industry. 


\section{Indian FinTech Scenario}

It is well-known that the Financialsector a cross the world, more specifically in India, is undergoing a digital revolution. As per Fintech Global, Indian FinTech firms have raised over $\$ 13$ billion through more than 460 deals since 2014. Many researchers have studied the emergence, evolution a nd effect of FinTech and Technology in Fina ncial services [912]. The Fin Tech business has phenomenally grown and no more made up of only new start-up companies, the Fin Tech industry has many seasoned firm s that provide a wide ra nge of financial services and functions at a international level. In Emerging markets, FinTech adoption is much higher than the global avera ge. India and China were leading the FinTech a doption index in 2019.

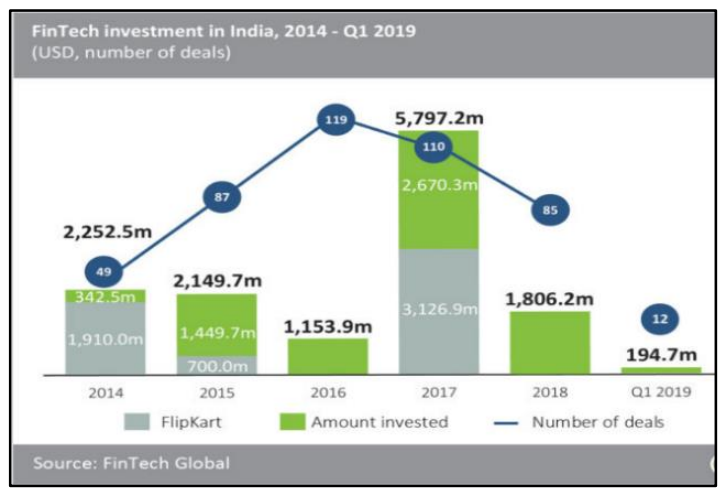

Fig. 5. Investments in World-wide Fintech Companies (in billion US\$)

Some of the challenges faced by Indian FinTech firm s a re; (i). Small and inexperienced management teams who lack the capability, (ii). Fewer financial and economic resources that avert appropriate sca ling, (iii). Ina dequate credit facilities and la ck of startup exposure, (iv.) Non-availability of established business models, (v). Failure to a ttract talents in analytics domain and skillful personnel, (vi) Lack of full compliance knowledge and (vii). Absence of more reliable, transparent, secured and speedily information processing and customer service.

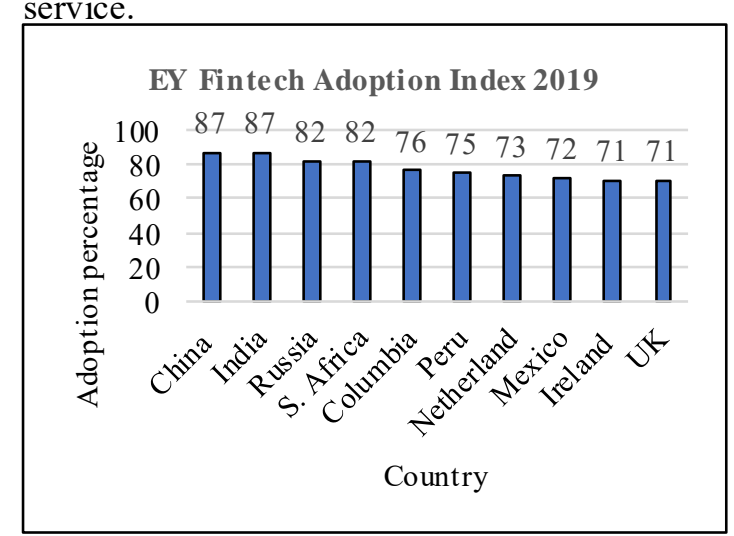

Fig. 6. Fintech Adoption Ind ex by Country Source: EY FinTech Adoption Index 2019
5G technology will certainly address the challenge of transparent, secured speedily process of data. The higher penetration of smartphone consumers and persistent build-up of the digital infra structure will enable quicker a doption of $5 \mathrm{G}$ in the FinTech industry. India's FinTech sector is thriving and changing the financial services landscape to achieve a secure and comprehensive financial environment. FinTech offers chances to expand financial services to all members of the society, particularly the deprived and financially excluded, through better access to information and lending.

\section{$65 \mathrm{G}$ and FinTech effects on Banking and Financial Sector}

Post Financial Crisis, FinTech firms progressed rapidly which enables to raise the question of whether or not FinTech companies a re heading to replace tra ditional banks and financial institutions. However, many believe that banks and financial institutions are going to a dopt fintech developments into their core businesses and successfully overcome this transition phase. Similarly, the ongoing $5 \mathrm{G}$ implementation along with FinTech revolution, is expected to have a massive change in the way banks are functioning. There is a lso a view that banking and financial institutions cannot embrace $5 \mathrm{G}$ service and enhanced financial technology instantly because of strict regulations. Though regulating guidelines are not a hindrance to innovation and change, the strict guidelines will keep the banks under the pressure of preventive actions to attempt innovative process and a ctions. Most used FinTech services are for Transfers \& Payments, Insurance, Sa vings and Investments, Borrowing and Financial Planning Advantages of $5 \mathrm{G}$ technology along with FinTech innovations a re; More a ccessible financial markets for ordinary consumers and Easy distribution of financial services.

The challenge in banking and financial services sector is to ensure perfect competition and greater transparency. As the competition increases, there will be a wide range of quality and assortment of banking products. Higher transparency in banking services helps the customers to understand the offerings much better. Fintech businesses with the a doption of $5 \mathrm{G}$ technology are predicted to expand the services presently being provided by the traditional banks and technology-driven financial firms. As FinTech firms are entering into a new period of growth, regulating a uthorities a re having a constant eye on them to protect consumers and look for objectionable practices. FinTech firms have mainly created disruption for big banks and a ge-old financial service firms. One of the common examples of such disruption can be witnessed in a qua ntum of mobile applications (apps) that provide 
sha re trading without levying charges per trade from users. Despite all the efforts, the speed of technology adoption has not as expected compared to its potential and hence there are gaps in the penetration of financial services. Although FinTech is creating the banking experience more instinctive, tailored and empowering, the convergence of growing technologies and financial services holds the key to make a robust digital Indian economy. Equipped with better data management, analytics competencies and nearly zero process cost, FinTech firms are supplementing and in certa in a reas competing the existing banking and financial institutions world wide. Be it exploring new financial segments or making an inroad into foreign markets, Indian FinTech start-up firms are chasing several ambitions. As per NASSCOM, India's FinTech software market is predicted to reach US\$ 2.4 billion by the end of 2020 .

India's age-old cash transaction-based economy has responded superbly to the FinTech prospect which is mainly because of e-commerce boom and smartphone usage growth. The domains that Fintech affects in banking and financial services are: (a) lending, deposit, investment and financing services; (b) remittances, clearing and settlement, and payment services, (c) Trading advisory and investment management, and (d) insurance. The rea lity is very few banks in India are having a robust financial forte to achieve global competency. FinTech is an ideal path to emerge as a robust institution in digital payments and transactions. According to the Payments Council of India, the digital payments industry has a higher growth rate than before the demonetization period. Many FinTech companies combine automated analysis of retail customers with user-friendly interfaces tooffer financial services that are more appropriate at a lesser fee. One suitable example is that 'marketplace lending' platforms have become a new lending forum that entices borrowers because of its easy and simple loan application method. Traditional banks and financial service firms have seen technology as a support system to business propositions, rather than creating new business propositions themselves. But, FinTech firms a re changing that function by taking a dvantage of digital technologies in order to make innovative business propositions and target new market segments. The effect of new technologies on banks and financial firms due to innovative frameworks like blockchains and cryptocurrencies are already disrupted the way industry functions and yet to witness the full impact. However, the likely benefits of these technologies are adequate to induce significant attention from technology-savvy people, entities and governments.

India's financial intermediation cost is high at 3.15 percent compared to 2 percent in advanced nations (Payments Council of India report, 2017).
Application of $5 \mathrm{G}$ services in FinTech companies may help to reduce this existing high intermediation cost which will benefit the consumers ultimately. The convergence of information technology, financial services and regulatory guidelines will play a significant part in creating a robust Indian digital economy (Digita 1 Money Conference, 2017). Some of the leading fintech companies are effectively conducting their operations in India are Policy Bazar, lending kart, Pay Sense, Mobikwik. Capital Float, Bank Bazar, Paytm, PhonePe, PayU etc. These companies are looking forward to using $5 \mathrm{G}$ services to enhance their business and improve enduser satisfaction.

Table.2. Electronic clearing and Card Payments

\begin{tabular}{|l|c|c|c|c|}
\hline \multirow{2}{*}{ Item } & \multicolumn{2}{|c|}{ Volume (Million) } & \multicolumn{2}{c|}{ Value (Rs. Billion) } \\
\cline { 2 - 5 } & $\begin{array}{c}2017- \\
18\end{array}$ & $\begin{array}{c}2018- \\
19\end{array}$ & $\begin{array}{c}2017- \\
18\end{array}$ & $\begin{array}{c}2018- \\
19\end{array}$ \\
\hline $\begin{array}{l}\text { Total } \\
\text { Retail } \\
\begin{array}{l}\text { Electronic } \\
\text { Clearing }\end{array}\end{array}$ & 6,382 & 12,467 & 193,113 & 267,515 \\
\hline $\begin{array}{l}\text { Total } \\
\text { Card } \\
\text { Payments }\end{array}$ & 8,208 & 10,781 & 10,607 & 14,097 \\
\hline
\end{tabular}

Source: RBI Annual Report, 2019

\section{$75 \mathrm{G}$ and FinTech - Conclusion and a Way Forward}

The disruptions created by these new digital revolutions has the possibility to reduce the role and significance of the existing banks. The banks started acknowledging that they require to come out of institutional complacency. In the coming days, banking and financial services will be like a layer on which the whole system is built on. It is no more monopoly or oligopoly market in the finance and banking industry. To sustain and grow in the industry and to becomemore competing banks have to implement 5G technology and collaborate with FinTech companies. Numerous startup companies a re looking forward to speeding up their progress by means of a faster, a ffordable and wider distribution of services contrary to the old generation financial institutions which a re costlier and lagging in service quality. In the forthcoming years, banks are expected to either outsource or start the job of technology management with external firms which allows them to focus on the core business and risk management a spects. All physica loperating venues of banks may be closed a most of them a renow on the path to get their process digital, and this becomes more possible with $5 \mathrm{G}$ technology. The social and economic transformation potential through FinTech is very high. Many view $5 \mathrm{G}$ and FinTech as $4^{\text {th }}$ industria 1 revolution. The emergence of $5 \mathrm{G}$ mobile technology along with FinTech firms is just thenew innovative trend to disturb the banking sector, it is 
expected that a lot of innovations are in the pipeline for ba nking and financial service sector. Despite all the merits, one of the main challenges for Fin Tech companies is to collaboratewith banks is the cultural differences. However, in the recent past, many big banks are transforming into a shared service model in various areas like due-diligence and technology, this is where the FinTech firms can capitalize on the collaborative ben efits. As Fintech signs the new era of banking and financial services, it is indeed not the solution for all open problems. It is equally an improving drive and a disruptive force; it requires to be affected thoughtfully.

According to an information services firm Markit's 5G economic impact study, "5G mobile value chain alone can generate revenue up to $\$ 3.5$ trillion by 2035 and support up to 22 million jobs". A report on The guide to capturing the $5 \mathrm{G}$ industry digitaliza tion business potential, suggests operators could grow revenues between $12-36 \%$ (revenue of \$204-\$619 Billion) to their current forecast service revenue of $\$ 1.7$ Trillion in 2026 . This would mean a $13.6 \%$ annual growth against current operator service revenue growth targeted at $1.5 \%$. Technology is not just a change enabler, but, a driver of innovation as we a lready seeing the emergence of high impact technologies in banking and financial services industry, especially in FinTech. [13] analyzed the likely impact of $5 \mathrm{G}$ on the Society. Along with $5 \mathrm{G}$, technologies such as Artificial intelligence, IoT, Cloud computing, Quantum computing and Blockchain are expected to change the nature of services and how the way the financial services are offered to the customers. Overall, these technologies will combine to redefine the bankcustomer relationship forever. Despite getting huge customers in recent time, FinTech and neo banks are still facing a lack of trust among many people, most of them even suspect the existence of these institutions after a year or two. The government's strong signal to support and nurture these institutions will go a long way in creating trust. There is also a possible gender split, with FinTech adoptability by females may be very meagre. Even among the users, many do not use FinTech and digital banks as a primary account. By implementing a robust legal and regulatory framework. The technologies like $5 \mathrm{G}$, AI and blockchain would be highly beneficial in various fields for the world to adapt to. It will certainly improve efficiency and remove the biases that sneak into the financial system. [14] found that the normal cost of intermediation is held firm at about $2 \%$ of the transaction value. $5 \mathrm{G}$ technology can benefit to minimize operational a nd a dministrative overheads, potentially to the advantage of both FinTech companies and their customers.

\section{References}

1. S. Sriniva san, Big da ta and financial fraud using fintech methods (Working paper). Houston, TX: Texas Southern University. (2016).

2. W. Kim, R. Mauborgne, Blue ocean strategy. Harvard Business Review. 82, 10 (2004).

3. S. Newell, M. Mara belli, Strategic opportunities (and challenges) of a lgorithmic decision making. A call for action on the long-term societal effects of datafication. Journal of Strategic Information Systems, 24, 1 (2015).

4. A. V. Thakor, Information technology and financial services consolidation, Journal of Banking \& Finance, 23, (1999).

5. I. Aldridge, S. Krawciw, Real-time risk: What investors should know about fintech, highfrequency tra ding and flash crashes, Hoboken, NJ: Wiley (2017).

6. S. R. Das, The future of FinTech, Financial Management, 48, (2019).

7. R. Nolan, Ubiquitous IT: The case of theBoeing 787 and implications for stra tegic IT research, Journal of Strategic Information Systems, 21, 2 (2012).

8. T. Berg, V. Burg, A. Gombović, M. Puri, On the rise of fintechs: Credit scoring using digital footprints, The Review of Financial Studies, 33, 7 (2019).

9. O. Acar, Y. E. Citak, FinTech Integration process for Banks. $3^{\text {rd }}$ World Conference on Technology, Innovation and Entrepreneurship, Procedia Computer science (2019).

10.K. Leong, A. Sung, Fin Tech: What is it and How to Use Technologies to create business value in FinTech way?, International Journal of Innovation, Management and Technology, 9, 2 (2018).

11. M. Kaur, Digita lCurrency and its implication for India, The Management Accountant, 54, 11 (2019).

12.A. Fuster, M. Plosser, P. Schnabl, J. Vickery, The role of technology in mortgage lending, The Review of Financial Studies, 32, 5 (2019).

13. Abel Nyamapfene, The Impending 5G Era and its Likely impact on Society. Journal of independent Studies and Research, 14, 1 (2016).

14. T. Philippon, The fintech opportunity. (Working paper). Manhattan, NY: New York University (2016). 